\title{
Comparative evaluation of DNA extraction from rice's root- associated bacterial consortium for population structure study
}

\author{
Nichapat Kittiborwornkul ${ }^{1}$, Anne Sahithi S.T ${ }^{2}$, Jirapa Phetsom $^{3}$, Theerawut Phusantisampan ${ }^{4}$, Wasinee Pongprayoon ${ }^{5}$, \\ Malinee Sriariyanun ${ }^{1,6^{*}}$
}

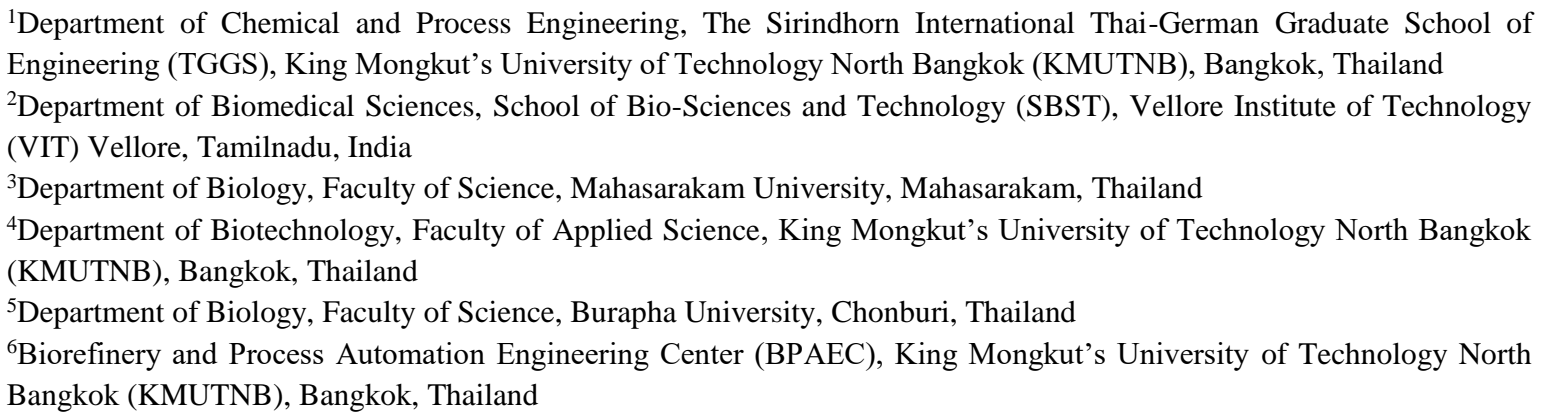

\begin{abstract}
Understanding in population structure of a plant's root-associated microbiome is applied in good practices in agricultural activities to improve production yields and enhance plant immune responses. The molecular analysis of bacterial populations inhabited in soil faces difficulties in obtaining high yield and high purity of DNA, and different commercial DNA extraction kits have been developed for this purpose. This study focuses on the comparison of DNA extraction of six different rice root-associated bacterial consortium using three commercial kits with two key technologies, spin-column adsorption and magnetic bead adsorption. The quality and quantity of genomic DNA obtained from these extraction methods were analyzed and compared based on DNA concentration, DNA purity and efficiency to be used as a template for 16sRNA amplification. The results showed that the extraction kit with magnetic bead adsorption technology showed the highest concentration $(101.32 \mathrm{ng} / \mu \mathrm{l})$ compared to other DNA extraction kits $(32.67$ and $1.89 \mathrm{ng} / \mu \mathrm{l}$ ). The purity values (A260/A280) were assessed by using Nano-drop spectrophotometer and resulted in purities of nucleic acids in the range of 1.4-1.7. Thus, it was concluded that the extracted DNA obtained from the extraction kit with magnetic bead adsorption technology can be valuable for molecular analysis of microbial communities present in the soil.
\end{abstract}

Keyword. DNA extraction method, Bacterial consortium, Rice, Root-associated microbiome, Population analysis

\section{Introduction}

Cereals play an essential role in the human daily diet, which is rich in nutrients and calorie composition [1]. Rice is one of the most economically and nutritionally important cereals, with about $60 \%$ of the world's population consuming rice as a basic diet. In addition, rice is the most cultivated crop in the Asia-Pacific region and is the staple food of some developing countries [2] and its by-products could be converted to various valueadded products [3]. Some rice cultivars were characterized to contain beneficial nutrition to improve human health [4]. In rice cultivation, several microorganisms are involved for the growth and can also cause disease resulting in reduce yields [5], [6-7]. The study of microorganisms present in the soil helps to improve their productivity. Some species of these microbes provide the benefit to rice by activating the defense mechanism to protect plants from pathogens [8].

\footnotetext{
* Corresponding author: macintous@gmail.com
}

However, culturing microorganisms from soil samples in laboratory is difficult, and understanding the diversity and ecology of microorganisms is a fundamental obstacle [9]. Several factors are demonstrated to involved in soil pollution, which reduce the viability of soil microbes [10]. In addition, microorganisms are important to produce carbon, nitrogen and many other organic matters for plants. Due to the high contamination of the soil with organic substances, it can lead to rupture of cells and the removal of humic acids that may interfere with the polymerase activity during DNA amplification reaction in laboratory for studying soil microbe's population [11]. Therefore, many strategies and techniques have been developed to help researchers to be able to handle the samples for further research.

DNA-based techniques can overcome this obstacle by understanding the genes involved in microorganisms [12]. Extraction of large amounts of high-quality DNA from the rice plant can be used for further genetic 
analysis. Methods for extracting DNA from soil are quite complex because the soil is contaminated to the level that is not suitable to be manipulated at the molecular level [13]. DNA is primarily characterized by high molecular weight (MW) fragments with an A260 / 280 ratio of 1.8-2.0, and the presence of contaminants such as polysaccharides and phenols can reduce DNA quality [14]. Polysaccharides released from plant's exudates can be contaminated in DNA extraction resulting in DNA precipitation and reduce the extraction yields of DNA. Anionic impurities inhibit restriction enzymes and interfere with enzymatic DNA analysis [15] and RFLP and PCR-based molecular analysis of dried seeds of different cereals [16]. Rapid and pure extraction of DNA is a required for assessing advanced techniques such as fingerprinting, marker-assisted breeding, gene mapping, and the authenticity of exported variety of cereals [17]. There are several methods for extracting DNA from plant tissue, but these methods produce small amounts or varying qualities of DNA. Several methods raised for the DNA extraction are altered versions of cetyltrimethyl ammonium bromide (CTAB) extraction, with some limitations, which vary in time and cost. CTAB is a cation surfactant added to a DNA extraction buffer that dissociates DNA from histone proteins and selectively precipitates it [18]. Even though DNA extraction protocols have become much more advanced in recent years, they still have their advantages and disadvantages. In addition, commercially available genome isolation kits have significant limitations when extracting genomic DNA of higher concentrations (especially from soil samples) [19].

This study focuses on the comparison of DNA extraction using different commercial kits, which refer to different extraction technologies for DNA from contaminated soil samples. Six different rice root associated bacterial consortium samples were taken to extract DNA using three commercial kits with two key technologies, spin-column adsorption and magnetic bead adsorption. These kits are (1) Bioneer MagListo ${ }^{\mathrm{TM}}$ 5M Genomic DNA Extraction Kit, (2) PureDireX Genomic DNA Isolation Dual Kit and (3) QIAamp ${ }^{\circledR}$ DNA Mini Kit. The quality and quantity of genomic DNA/g of contaminated soil were analyzed and compared using these kits. This comparative study was performed to determine the effectiveness of the kit in extraction DNA from soil to be preliminary data to select suitable method for further study in soil microbial population.

\section{Material and methods}

\subsection{Raw materials}

Rice berry roots with soil samples were obtained from research rice field in Eastern part of Thailand. The soil samples were separated from roots to three different compartments, root associated soil, root proximity soil and bulky soil, as shown in (Figure 1). Two biological replicates were collected from the same rice field, resulting in a total of 6 different samples Table 1. Firstly, to obtain root proximity sample, soil particles attached with rice root (not thicker than $10 \mathrm{~mm}$ from root's perimeters) were taken out by hands. Then these rice roots were dipped in phosphate buffer $(\mathrm{pH} 7.0)$ and vortex for $5 \mathrm{~min}$ to detach the root-associated soils from root. Then the root-associated soils were collected by centrifugation at $8,000 \mathrm{rpm}$ for $10 \mathrm{~min}$. After that $1 \mathrm{~g}$ of each soil sample was taken and $20 \mathrm{ml}$ of nutrient broth were added to enrich bacterial growth. The cultures were incubated in rotary shakers $30{ }^{\circ} \mathrm{C}$ for 72 hours. The growths of soil's bacterial cultures obtained from 6 soil samples were measured by using spectrophotometer at the wavelength of $600 \mathrm{~nm}$ to monitor culture's turbidity. Then, the cultures were diluted with phosphate buffer to prepare the same amounts of bacterial cultures for testing with 3 different commercial kits. $15 \mathrm{ml}$ of diluted sample was taken and centrifuged at $6000 \mathrm{rpm}$ for $10 \mathrm{mins}$, pellet was stored for further analysis of DNA extraction.

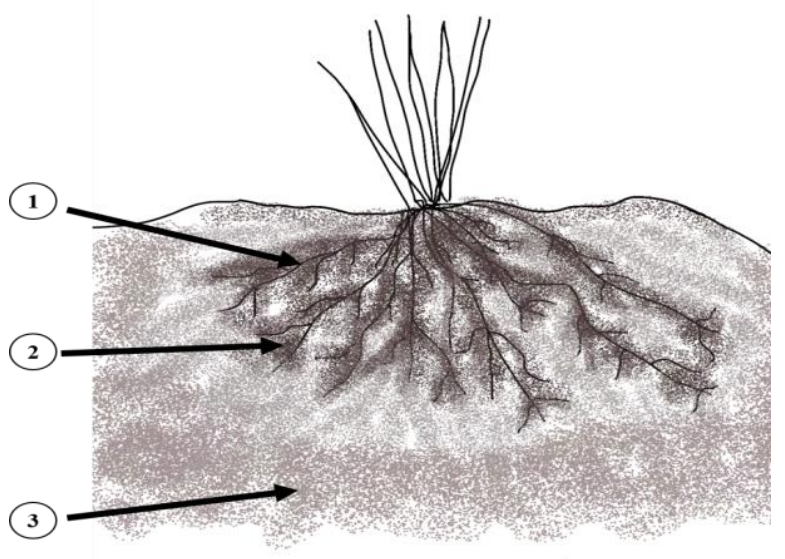

Fig. 1. A schematic diagram of the rice berry root. 1. Root associate soil (within $2 \mathrm{~mm}$. from root's perimeters) 2. Root proximity soil (within $10 \mathrm{~mm}$. from root's perimeters) 3 . Bulky soil (more than $10 \mathrm{~mm}$.).

Table 1. Six soil samples used for the extraction of bacterial consortium's DNA.

\begin{tabular}{ccc}
\hline No & Sample & Source \\
\hline 1 & Soil from Rice berry rep. 1 & root proximity soil \\
2 & Soil from Rice berry rep. 1 & root associate soil \\
3 & Soil from Rice berry rep. 2 & root proximity soil \\
4 & Soil from Rice berry rep. 2 & root associate soil \\
5 & Soil from Rice berry rep. 1 & bulky soil \\
6 & Soil from Rice berry rep. 2 & bulky soil \\
\hline
\end{tabular}

\subsection{Extraction DNA}

The DNA was extracted using three commercial kits with two key technologies, spin-column adsorption (PureDireX Genomic DNA Isolation Dual Kit, QIAamp ${ }^{\circledR}$ DNA Mini Kit) and magnetic bead adsorption (Bioneer MagListo $^{\mathrm{TM}}$ 5M Genomic DNA Extraction 
Kit). The major steps for these DNA extraction kits were composed of cell harvesting, cell lysis, DNA binding, Wash, and elution (Figure 2.). The experimental details of each step in each kit were followed by vendor's instructions as follows.

\subsubsection{Bioneer MagListo ${ }^{\mathrm{TM}}$ 5M Genomic DNA Extraction Kit}

The genomic DNA was extracted from cultured cells $\left(1 \times 10^{6}\right)$ by centrifugation for 10 minutes at $3000 \times \mathrm{g}$. The pellet was suspended in $200 \mu$ l of 1 X PBS. $20 \mu 1$ of Proteinase $\mathrm{K}$ and $10 \mu \mathrm{l}$ of RNase A was added and incubated for $2 \mathrm{~min}$ at room temperature. Then $200 \mu \mathrm{l}$ of GB buffer added and mixed by vortexing, incubated at $60^{\circ} \mathrm{C}$ for $10 \mathrm{~min}$. After incubation $400 \mu \mathrm{l}$ of absolute ethanol and $100 \mu \mathrm{l}$ of Magnetic Nano Bead Solution was added and mixed thoroughly by vortexing. The samples were placed in MagListo ${ }^{\text {TM}}-2$ Magnetic Separation Rack and gently inverted for 3-4 times. The supernatant was collected without removing the tube from MagListo ${ }^{\mathrm{TM}}$ rack. Then the magnet plate was detached from the stand and $700 \mu 1$ of WM1 buffer was added and vortexed. Magnet plate was attached again and inverted the tube gently for 3-4 times the beads started binding tightly to the magnet. The supernatant was collected without removing tube from the rack. This was repeated for 2 times. Supernatant was washed by adding W2 buffer of $700 \mu \mathrm{l}$. The $3 \mathrm{rd}$ wash was done by adding $700 \mu \mathrm{lWE}$ Buffer to the opposite side of the bead pellet and gently inverted twice after closing the cap. Later, EA buffer of $100 \mu \mathrm{l}$ was added and mixed vortexing at $60^{\circ} \mathrm{C}$ on elution stand for $1 \mathrm{~min}$.

\subsubsection{PureDireX Genomic DNA Isolation Dual Kit}

Cultured bacterial cells (up to 109) were transferred to $1.5 \mathrm{ml}$ micro centrifuge tube. The tube was centrifuged at $12000 \mathrm{x}$ g for $1 \mathrm{~min}$. Supernatant was removed and the pellet was suspended in $50 \mu \mathrm{l}$ of buffer CR by pipetting. Then $300 \mu \mathrm{l}$ of CC buffer was added and incubated at $60^{\circ} \mathrm{C}$ for 10 mins by inverting the tube for every $3 \mathrm{~min}$. for the removal of protein $400 \mu$ of buffer $\mathrm{CB}$ was added mixed thoroughly and centrifuged at $12000 \mathrm{x}$ g for $1 \mathrm{~min}$. The sample was placed in a $2 \mathrm{ml}$ collection tube and supernatant was transferred to the previous step of $\mathrm{CC}$ column. Centrifuged at $14000 \mathrm{x} \mathrm{g}$ for $30 \mathrm{secs}$ and discarded the flow collected in the tube. The sample was washed using $400 \mu \mathrm{l}$ of buffer W1 into the column $\mathrm{x} \mathrm{g}$ for 2 mins. The liquid collected in the tube column CC was discarded. DNA was eluted by transferring the dried $\mathrm{CC}$ to a new $1.5 \mathrm{ml}$ of micro centrifuge tube. TE buffer of $200 \mu \mathrm{l}$ was added to the center of the column and incubated at $60{ }^{\circ} \mathrm{C}$ for $3 \mathrm{~min}$. Column was centrifuged for $2 \mathrm{~min}$ at $14000 \mathrm{x} \mathrm{g}$ to elute the purified DNA.

\subsubsection{QIAamp® DNA Mini Kit}

Extraction of DNA was done using $220 \mathrm{mg}$ of sample in a $2 \mathrm{ml}$ centrifuge tube place on ice. $1 \mathrm{ml}$ of EX buffer was added to the sample and vortexed thoroughly until homogenized. The sample was centrifuged for $1 \mathrm{~min} .15$ $\mu \mathrm{l}$ of proteinase $\mathrm{K}$ was taken in a $1.5 \mathrm{ml}$ tube and the supernatant of $200 \mu \mathrm{l}$ was collected from centrifuged tube. $200 \mu \mathrm{l}$ of buffer AL was added to the sample and
QIAamp Fast DNA Stool Mini Kit

STEP 1 Cells Harvesting

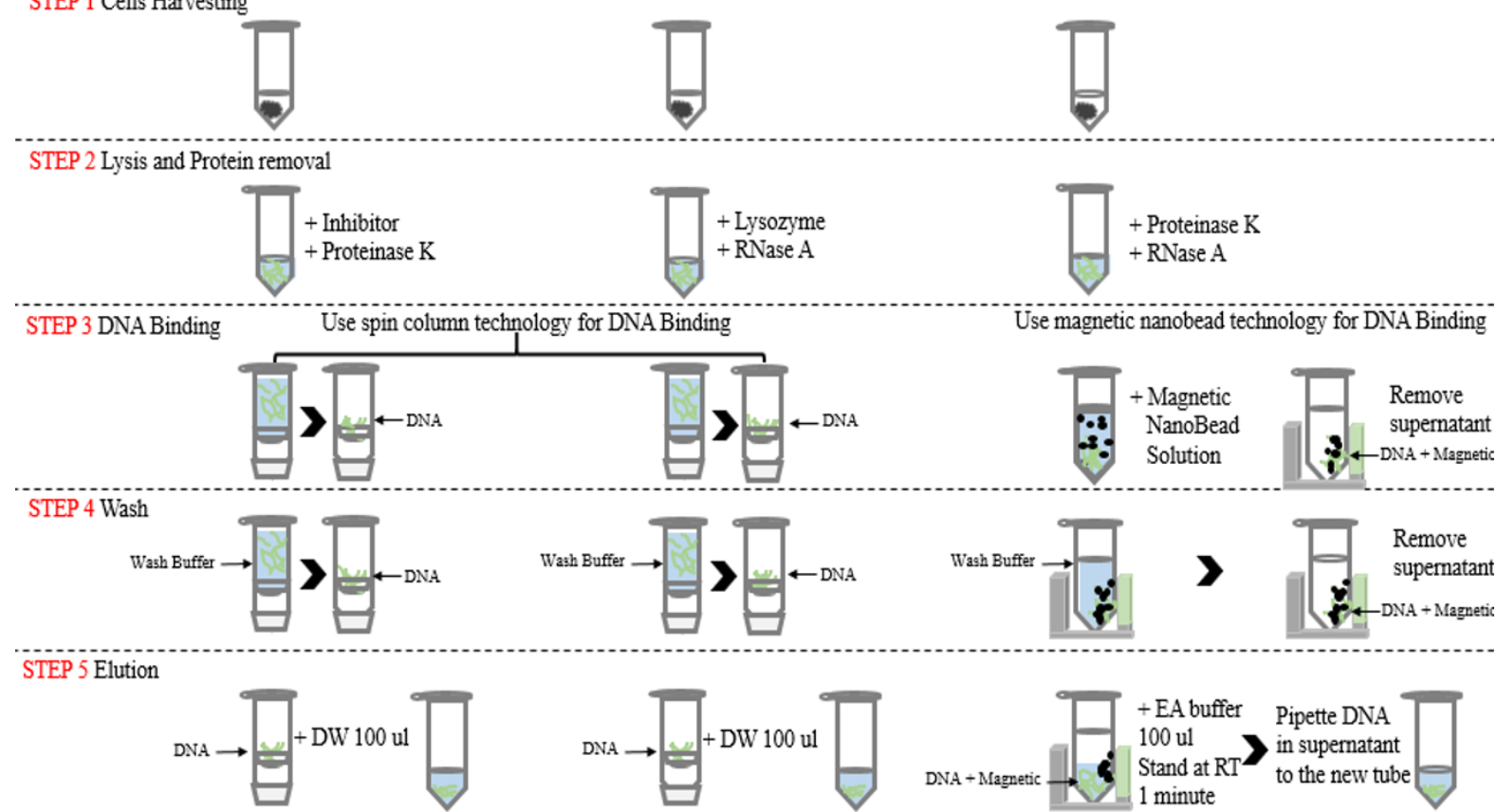

Fig. 2. Summarization of three DNA extraction kits with two key technologies; spin column and magnetic nanobead. 
vortexed for $15 \mathrm{secs}$, incubated at $70^{\circ} \mathrm{C}$ for $10 \mathrm{~min} .600$ $\mu l$ of ethanol was added and mixed thoroughly. Then the lysate of $600 \mu \mathrm{l}$ was added to QIAamp spin column in a $2 \mathrm{ml}$ collection tube. The filtrate was discarded by repeating 2 times. $500 \mu \mathrm{l}$ of buffer AW1 was added to the spin column and centrifuged for $1 \mathrm{~min}$. QIAamp spin column was placed in a new $2 \mathrm{ml}$ collection tube and the filtrate was discarded. QIAamp spin column was opened carefully, $500 \mu \mathrm{l}$ of buffer AW2 was added and centrifuged foe $3 \mathrm{~min}$, filtrate was discarded. Then spin column was placed in a new collection tube and the old collection tube filtrate was discarded. Spin column was centrifuged for $3 \mathrm{~min}$. QIAamp spin column was transferred in to a new $1.5 \mathrm{ml}$ centrifuge tube and $200 \mu \mathrm{l}$ of ATE buffer was added on to the QIAamp membrane, incubated at RT for $1 \mathrm{~min}$. the tube was centrifuged for 1 min to elute the DNA.

\subsection{DNA quantitation and analysis}

To evaluate the quantity and quality of the DNA samples (3 soil samples x 2 biological replicates x 3 kits) Nano400A Micro-Spectrophotometer was used (ALLSHENG). $2 \mu$ of DNA extracted from the sample was used to determine the DNA purity based on the values of A260/A280 ratio and A260/A230 ratio. The concentration of each DNA sample was determined automatically from the Nano-400A MicroSpectrophotometer. To determine the integrity of genomic DNA and analysis of PCR products, the sample was analyzed by gel electrophoresis with $2 \%$ agarose (for genomic and amplified DNA). Electrophoresis was performed using $1 \mathrm{x}$ TBE buffer along with SyBR ${ }^{\circledR}$ Green staining. The setup was performed by constant voltage of $120 \mathrm{~V}$ for 50 mins.

\subsection{Polymerase Chain Reaction (PCR)}

The amplification of the 16S rRNA fragment of extracted DNA sample was conducted using 16S rRNA primers. For PCR analysis, the sample was amplified with forward primer P1: 5AGAGTTTGATCCTGGCTCAG-3 and reverse primer P2: 5-GGTTACCTTGTTACGACTT-3 [8]. Each PCR reaction contains $25 \mu \mathrm{l}$ containing mixture of $(10 \mathrm{x}$ buffer, dNTP, primers, Taq DNA Polymerase, MgCL2, $\mathrm{H} 2 \mathrm{O}$, and DNA template). The PCR reaction setup per reaction and conditions are shown in the (Table 2 and Table 3) was analyzed by gel electrophoresis with $2 \%$ agarose (for genomic and amplified DNA). Electrophoresis was performed using 1x TBE buffer along with $\operatorname{SyBR} \AA$ Green staining. The setup was performed by constant voltage of $120 \mathrm{~V}$ for 50 mins.

\section{Results}

To prepare the same number of bacterial cells for DNA extraction with different extraction kits, the bacterial cell density of each cultured sample (after $72 \mathrm{hr}$ ) was determined by taking $1 \mathrm{ml}$ from each sample with spectrophotometer at the wavelength of $600 \mathrm{~nm}$. The absorbance values of cell density were shown in the Table 4. It was observed that soil sample in the region of root proximity and bulky soil had higher absorbance value when compared to root associated samples. These variations of cell turbidities of each soil samples could imply to variations in starting numbers of cells as well as the species in original samples, when all of them were cultured under the same nutrients and conditions.

Table 2. PCR Master mix components per reaction

\begin{tabular}{lc}
\hline PCR Mixer Components & Volume $(\boldsymbol{\mu l})$ \\
\hline 10x Buffer & 2.5 \\
dNTP & 0.5 \\
Forward Primer & 0.5 \\
Reverse Primer & 0.5 \\
Taq DNA Polymerase & 0.25 \\
$\mathrm{MgCl}_{2}$ & 0.75 \\
$\mathrm{H}_{2} \mathrm{O}$ & 19 \\
DNA Template & 1 \\
\hline Total volume & $\mathbf{2 5}$ \\
\hline
\end{tabular}

Table 3. Condition for PCR amplification

\begin{tabular}{cccc}
\hline Step & Temperature $\left({ }^{\circ} \mathbf{C}\right)$ & Time & Cycles \\
\hline Hot Start & 95 & $5 \mathrm{~min}$ & \\
Denature & 95 & $50 \mathrm{sec}$ & \\
Annealing & 57 & $50 \mathrm{sec}$ & 40 cycles \\
Extension & 72 & $90 \mathrm{sec}$ & \\
& 72 & $5 \mathrm{~min}$ & \\
\hline
\end{tabular}

Then, all bacterial cultures were subjected to DNA extractions with 3 commercials kits. The quality and quantity of final product DNA from each sample (3 soil samples $\mathrm{x} 2$ biological replicates $\mathrm{x} 3$ kits) was determined by using Nano-400A MicroSpectrophotometer (Table 5-7). It was found that the highest concentration of DNA was found in Bioneer MagListo TM 5M Genomic DNA extraction kit (magnetic bead technology) of about $101.32 \mathrm{ng} / \mu \mathrm{l}$ compared to other DNA extraction kits PureDireX Genomic DNA Isolation Dual Kit and QIAamp ${ }^{\circledR}$ DNA Mini Kit (spincolumn technology) $32.67 \mathrm{ng} / \mu \mathrm{l}$ and $1.89 \mathrm{ng} / \mu \mathrm{l}$. The purity values (A260/A280) indicate significant levels for contaminations of nucleic acids in the range of 1.4-1.7. The concentration of DNA extracted using Bioneer MagListo TM 5M Genomic DNA extraction kit for all six samples was shown in the Table 5. Among them, DNA extracted from soil sample in the region of root proximity was observed $(101.32 \mathrm{ng} / \mu \mathrm{l})$ comparatively 
higher than the region of bulky soil $(54.33 \mathrm{ng} / \mu \mathrm{l})$. The yield of DNA extracted using PureDireX Genomic DNA Isolation Dual Kit was determined for all six samples was shown in the Table 6. Among them, DNA extracted from soil sample 5 has the highest yield with $35.56 \mathrm{ng} /$ $\mu \mathrm{l})$. DNA concentration of all six samples extracted using QIAamp ${ }^{\circledR}$ DNA Mini Kit was determined and shown in the Table 7. Among them, it was observed that DNA extracted from root proximity showed lowest value of $1.89 \mathrm{ng} / \mu \mathrm{l}$ when compared to bulk soil $(6.53 \mathrm{ng} / \mu \mathrm{l})$. The purity values of DNA extracted using kits for all six samples were also observed. It was found that the purity of the DNA was not significant. This implies the samples are contaminated by protein.

Table 4. Absorbance at $600 \mathrm{~nm}$ of cultured bacterial samples

\begin{tabular}{ccc}
\hline Sample & Source & $\begin{array}{c}\text { Absorbance } \\
600 ~ \mathbf{~ m}\end{array}$ \\
\hline 1 & Root proximity soil-rep1 & 1.174 \\
2 & Root associate soil-rep1 & 0.892 \\
3 & Root proximity soil-rep2 & 1.176 \\
4 & Root associate soil-rep2 & 0.945 \\
5 & Bulky soil-rep1 & 1.262 \\
6 & Bulky soil-rep2 & 0.905 \\
\hline
\end{tabular}

Table 5. Concentration of DNA obtained from Bioneer MagListo ${ }^{\mathrm{TM}}$ 5M Genomic DNA extraction kit.

\begin{tabular}{|c|c|c|c|c|}
\hline \multirow[t]{2}{*}{ Sample } & \multicolumn{3}{|c|}{ Absorbance } & \multirow{2}{*}{$\begin{array}{c}\text { DNA } \\
\text { concentration } \\
(\mathrm{ng} / \mu \mathrm{l})\end{array}$} \\
\hline & A260 & A280 & A260/A280 & \\
\hline 1 & 2.026 & 1.296 & 1.56 & 101.32 \\
\hline 2 & 1.703 & 1.195 & 1.43 & 85.19 \\
\hline 3 & 1.109 & 0.719 & 1.54 & 55.48 \\
\hline 4 & 1.014 & 0.618 & 1.64 & 50.72 \\
\hline 5 & 1.086 & 0.671 & 1.62 & 54.33 \\
\hline 6 & 0.368 & 0.239 & 1.53 & 18.41 \\
\hline
\end{tabular}

Table 6. Concentration of DNA obtained from PureDireX Genomic DNA Isolation Kit.

\begin{tabular}{|c|c|c|c|c|}
\hline \multirow[t]{2}{*}{ Sample } & \multicolumn{3}{|c|}{ Absorbance } & \multirow{2}{*}{$\begin{array}{c}\text { DNA } \\
\text { concentration } \\
(n g / \mu l)\end{array}$} \\
\hline & A260 & A280 & A260/A280 & \\
\hline 1 & 0.653 & 0.402 & 1.62 & 32.67 \\
\hline 2 & 0.578 & 0.400 & 1.44 & 28.95 \\
\hline 3 & 0.419 & 0.254 & 1.64 & 20.95 \\
\hline 4 & 0.581 & 0.381 & 1.52 & 29.07 \\
\hline 5 & 0.711 & 0.391 & 1.82 & 35.56 \\
\hline 6 & 0.326 & 0.229 & 1.42 & 16.31 \\
\hline
\end{tabular}

Table 7. Concentration of DNA obtained from QIAamp Fast DNA Stool Mini Kit.

\begin{tabular}{ccccc}
\hline Sample & \multicolumn{3}{c}{ Absorbance } & $\begin{array}{c}\text { DNA } \\
\text { concentration } \\
\text { (ng/ } \boldsymbol{\mu l})\end{array}$ \\
\cline { 2 - 4 } & $\mathbf{A 2 6 0}$ & $\mathbf{A 2 8 0}$ & $\mathbf{A 2 6 0 / A 2 8 0}$ & 1.89 \\
1 & 0.140 & 0.090 & 1.55 & 3.38 \\
2 & 0.067 & 0.039 & 1.71 & 4.23 \\
3 & 0.084 & 0.060 & 1.41 & 3.79 \\
4 & 0.075 & 0.050 & 1.50 & 4.49 \\
5 & 0.089 & 0.052 & 1.70 & 6.53 \\
6 & 0.130 & 0.092 & 1.41 & \\
\hline
\end{tabular}

The evaluations of intact genomic DNA were analyzed by gel electrophoresis. $1 \mathrm{~kb}$ ladder was used to determine the molecular size of the DNA samples (Figure 3). It was found that the DNA extracted using PureDireX Genomic DNA Isolation Dual Kit and QIAamp ${ }^{\circledR}$ DNA Mini Kit were observed while no band was shown in Bioneer MagListo TM 5M Genomic DNA extraction kit. This implies that the soil samples were highly contaminated with the organic compounds or chaotropic salts present in the purified DNA. In addition, it can cause the extraction process of DNA or during the removal of protein after the lysis step. Therefore, the sample extracted using Bioneer MagListo TM 5M Genomic DNA extraction kit is not efficient based on this criterion. DNA purity is required for PCR and sequencing, as well as a high molecular weight with less shear, no contamination of proteins, RNA or polysaccharides, and an absorbance of 260/280 nm of approximately $1.8-2.0$. To overcome this problem, PCR process was done to further evaluate DNA quality by using $16 \mathrm{~S}$ rRNA primers.

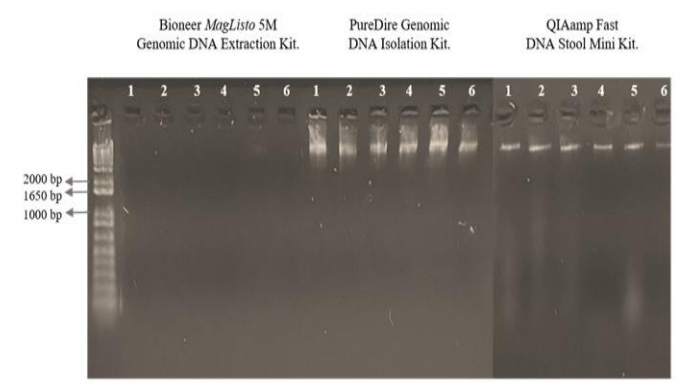

Fig. 3. Genomic DNA analysis in agarose gel electrophoresis (Lane 1-6 represents sample No. 1 - No. 6)

PCR reactions were set up to amplify the DNA obtained by extracting all three methods. The amplified product was separated on the Gel Electrophoresis (Figure 4). It was observed that 2 soil samples of (No.1 and No.4) extracted using the QIAamp ${ }^{\circledR}$ DNA Mini Kit band were shown and bp size was observed at about 1.4 $\mathrm{kbp}$, which is the targeted size of PCR reaction. Despite, this QIAamp ${ }^{\circledR}$ DNA Mini Kit spin column technology showed lowest measured concentration using Nano400A Micro- Spectrophotometer. Meanwhile, there were no PCR bands at all from samples extracted using Bioneer MagListo TM 5M Genomic DNA extraction kit 
that had the highest concentration observed in the Nanodrop.

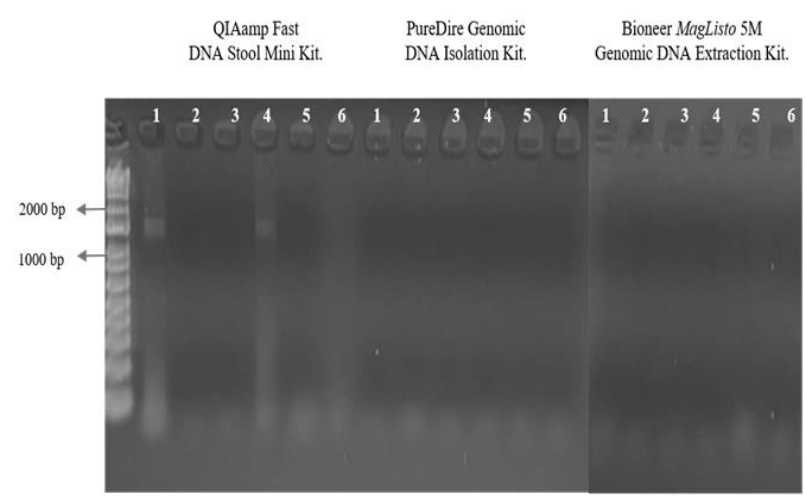

Fig. 4. Analysis of PCR products in agarose gel electrophoresis (Lane 1-6 represents sample No. 1 - No. 6)

Altogether, based on analysis of Nano-400A MicroSpectrophotometer, gel electrophoresis of genomic DNA and PCR amplification, the efficiency of different commercial DNA extraction kit was demonstrated. To avoid the interference of the magnetic beads and to reduce the loss of DNA samples. Some additional steps are recommended to remove the magnetic beads carefully to achieve DNA concentration of higher purity. However, methods are still yet to be developed to eradicate the interference of trace Nano-beads during the analysis of DNA. Therefore, it is concluded that the magnetic Nano-bead method must further be improvised to achieve the higher quantity of DNA for further molecular analysis. On the other hand, purity of the DNA samples is further necessary for the existing method. In conclusion, a more effective extraction technique must be developed for extraction of DNA in higher proportion and purity from soil samples. Further application of this work could incorporated to development of bioeconomy of using agricultural waste to produce value-added products [20].

\section{Conclusion}

In this study, the DNA was extracted from 3 different soil samples (Root associate soil, Root proximity soil and Bulky soil). The extraction of DNA was carried using two key technologies namely, spin column and magnetic Nano bead methods. This study was concluded with higher concentration of DNA extracted using Bioneer MagListo TM 5M Genomic DNA extraction kit from different soil samples. The concentration of DNA varied for soils collected from different regions. Though the DNA concentration was higher for magnetic Nano bead method. It was observed that the DNA bands were not identified or not visible when tested at a molecular level using PCR technique. It was concluded that DNA bands were not shown due to contaminated soil (organic compounds or chaotropic salts present in the purified DNA).

\section{Acknowledgment}

The authors would like to thank the King Mongkut's University of Technology North Bangkok (Grant Contract No. KMUTNB-BasicR-64-37) and Thailand Science Research and Innovation (Basic Research Fund Contract No. 4.3/2564) for financial support of this work.

\section{References}

[1] A. Abdel-Latif and G. Osman, Comparison of three genomic DNA extraction methods to obtain high DNA quality from maize, Plant Methods. 13,1(2017): 1 .

[2] A. Cachada, T. Rocha-Santos, and A.C. Duarte, Soil and Pollution, Soil Pollution. (2018): 1-28.

[3] Y.S. Cheng, P. Mutrakulcharoen, S. Chuetor, K. Cheenkachorn, P. Tantayotai, E.J. Panakkal, M. Sriariyanun, Recent Situation and Progress in Biorefining Process of Lignocellulosic Biomass: Toward Green Economy, Applied Science and Engineering Progress. 13, 4 (2020): 299-311.

[4] N. Chairerk, P. Pongyeela, J. Chungsiriporn, and N. Rakmak, Ethanol Extraction of Active Ingredients and Antioxidants from Germinated Sangyod Rice, Applied Science and Engineering Progress. 14(1), (2021).

[5] H. Liu, L.C. Carvalhais, M. Crawford, et al., Inner Plant Values: Diversity, Colonization and Benefits from Endophytic Bacteria., Frontiers in Microbiology. 8, (2017).

[6] P. Songkumarn, P. Chaijuckam, V. Tongsri, and J.J.G. Guerrero, Expression Analysis of Defense Related Genes in Rice Response to Bipolaris oryzae, the Causal Agent of Rice Brown Spot, Applied Science and Engineering Progress. 12(2), (2018).

[7] P. Songkumarn, P. Chaijuckam, and J.J.G. Guerrero, Genetic Diversity and Aggressiveness of Bipolaris oryzae in North-Central Thailand, Applied Science and Engineering Progress. 12(2), (2018).

[8] W. Pongprayoon, T. Siringam, A. Panya, and S. Roytraku, Application of Chitosan in Plant Defense Responses to Biotic and Abiotic Stresses, Applied Science and Engineering Progress. 15(1), (2022)

[9] J.M. Awika, Major Cereal Grains Production and Use around the World, Presented at the January (2011).

[10] M.A. Mohamad Roslan, M.A. Naim Mohamad, and S. Mohd Omar, High-Quality DNA From Peat Soil For Metagenomics Studies: A Minireview On DNA Extraction Methods, Science Heritage Journal. 1, 2(2017): 01-06.

[11] M.D. Braid, L.M. Daniels, and C.L. Kitts, Removal of PCR inhibitors from soil DNA by chemical flocculation, Journal of Microbiological Methods. 52,3(2003): 389-393.

[12] M. Majaneva, O.H. Diserud, S.H.C. Eagle, M. Hajibabaei, and T. Ekrem, Choice of DNA extraction method affects DNA metabarcoding of 
unsorted invertebrate bulk samples, Metabarcoding and Metagenomics. 2, (2018).

[13] M. Sriariyanun, P. Yasurin, P. Pornwongthong and, K. Cheenkachorn, Production, purification and characterization of an ionic liquid tolerant cellulase from Bacillus sp. Isolated from rice paddy field soil, Electronic Journal of Biotechnology. 19, (2015).

[14] N. Atheeqah-Hamzah, C.S.Y. Yong, and U.K. Yusuf, Extraction of High-quality RNA from Metabolite and Pectin Rich Recalcitrant Calyx Tissue of Hibiscus sabdariffa L, Pertanika Journal of Tropical Agricultural Science. 43,4(2020).

[15] R. Backer, J.S. Rokem, G. Ilangumaran, et al., Plant Growth-Promoting Rhizobacteria: Context, Mechanisms of Action, and Roadmap to Commercialization of Biostimulants for Sustainable Agriculture, Frontiers in Plant Science. 9, (2018).

[16] R.S. Pickard and B.J. McKevith, The Role Of Cereals In The Diet, Using Cereal Science and Technology for the Benefit of Consumers. 89 (2005).
[17] R. Von Post, L. Von Post, C. Dayteg, M. Nilsson, B.P. Forster, and S. Tuvesson, A high-throughput DNA extraction method for barley seed, Euphytica. 130,2(2003): 255-260.

[18] S. Khalid, M. Shahid, N.K. Niazi, B. Murtaza, I. Bibi, and C. Dumat, A comparison of technologies for remediation of heavy metal contaminated soils, Journal of Geochemical Exploration. 182, (2017): 247-268.

[19] X. Ren, B. Kang, and Z. Zhang, Understanding tumor ecosystems by single-cell sequencing: promises and limitations, Genome Biology. 19,1(2018): 211.

[20] R. Akkharasinphonrat, T. Douzou, M. Sriariyanun, Development of ionic liquid utilization in biorefinery process of lignocellulosic biomass, King Mongkut's University of Technology North Bangkok International Journal of Applied Science and Technology, 10,2 (2017): 89-96. 